Conference paper (Original scientific paper)

UDC: 005.35:658(497.5)

https://doi.org/10.18045/zbefri.2020.2.521

\title{
Impact of board size and ownership concentration on agency costs: evidence for Croatian companies*
}

\author{
Marina Klačmer Čalopa ${ }^{1}$, Ivana Đunđek Kokotec ${ }^{2}$, Karolina Kokot ${ }^{3}$
}

\begin{abstract}
The main objective of this research paper is to examine the impact of board size and ownership concentration, representing corporate governance mechanisms, on agency costs in large Croatian companies. Furthermore, debt financing and firm growth are examined because those variables also have impact on agency costs. Agency theory defines a framework for the potential issue of the separation of ownership and management as well as for the conflict between stakeholders (principals) and managers (agents). The most significant principal-agent problems are agency costs, but they do not have a directly quantifiable value; hence, in this research paper, the asset turnover ratio is used as the approximation. Therefore, this research will empirically test the significance of the impact of board size, ownership concentration, debt financing and firm growth on agency cost in the observed period from 2014 to 2018 using panel data analysis. This research was conducted with large Croatian companies using data and information from official annual accounts primarily to ensure objectivity, standardization and comparability. Specifically, the analysis was conducted on 219 companies operating in two main categories of economic activity: Manufacturing (C) and Wholesale and retail trade $(G)$. The results indicate that board size has a significant but negative impact on agency costs. The results also indicate that debt and growth have a significant and negative impact on agency costs. Ownership concentration was not found to have significant impact.
\end{abstract}

Key words: agency costs, corporate governance, board size, ownership concentration, panel data analysis

JEL classification: $G 30, G 32, K 22$

\footnotetext{
* Received: 02-11-2020; accepted: 21-12-2020

1 Full Professor, University of Zagreb, Faculty of Organization and Informatics, Pavlinska 2, 42000 Varaždin, Croatia. Scientific affiliation: financial institution and capital markets, corporate governance, strategic management, human resources management strategy, institutional investors.Phone: +38542 390846.E-mail: marina.klacmer@foi.hr.

2 Teaching Assistant, University of Zagreb, Faculty of Organization and Informatics, Pavlinska 2, 42000 Varaždin, Croatia. Scientific affiliation: corporate finance, institutional investors, financial institutional and capital markets, business operations and strategic management. Phone:+38542 390848.E-mail: idjundjek@foi.hr.

3 Teaching Assistant, University of Zagreb, Faculty of Organization and Informatics, Pavlinska 2, 42000 Varaždin, Croatia. Scientific affiliation: corporate governance, strategic management, human resources management strategy.Phone: +38542 390888.Email: kkokot@foi.hr.
} 


\section{Introduction}

Aziz et al. (2015) claim that corporate governance explains processes and structures that are used for management within the company and that the aim of these practices is to increase the wealth of shareholders. According to this definition, corporate governance mechanisms aim to resolve agency problems and to protect the wealth of shareholders. Panda and Leepsa (2017) state that the agency problem began with the development of joint-stock companies but that organizations suffer from this problem in different forms. La Porta et al. (2000: 3) state that the agency problem is a situation in which "the insiders who control corporate assets can use these assets for a range of purposes that are detrimental to the interests of the outside investors". Bhojraj and Sengupta (2003: 456) state that the agency problem is "a risk that management acting in its self-interest would take actions that deviate from firm value maximization, as well as the risk that the manager is incompetent". Jensen and Meckling (1976) define a principal-agent relationship as a contract between the principal and the agent under which the principal engages the agent to perform services on their behalf. Jensen and Meckling (1976) argue that it is impossible with zero agency costs to ensure that the agent will make optimal decisions for the principal.

Eisenhardt (1989) states that the domain of agency theory is the relationship of the principal and the agent who are engaged in a principal-agent contract and who have different goals and attitudes towards risk. According to Florackis (2008), agency theory provides a unique, realistic, and empirically testable perspective on problems between the principal and the agent. Consequently, agency costs associated with the agency problem cannot be avoided if a principal hires an agent to manage companies. Bendickson et al. (2016) define two perspectives in agency theory: principal-agent research and positivist agency theory. Eisenhardt (1989: 59) states that these two perspectives "share a common unit of analysis: the contract between the principal and the agent" as well as assumptions about people, organizations, and information. According to Bendickson et al. (2016) the first perspective, principal-agent research identifies two possible agency problems: risk-sharing and agent monitoring. Eisenhardt (1989) claims that positivist agency theory is focused on identifying situations in which the principal and the agent have different goals and describes the governance mechanisms that limit the agent's self-serving behaviour. Cerović et al. (2011) state that agency costs are all of those tangible and intangible assets which the principal uses in the control of agent to ensure optimal capital exploitation. The main idea of this paper is to analyse the efficiency of the governance mechanisms that limit those agent behaviours which are in conflict with the principal's interest. Based on literature review and results of past studies the paper's hypotheses are as follows:

H1: Agency costs will be lower when companies have boards that are small in size.

H2: When the ownership concentration is greater, agency costs will be lower. 
The basis of this research paper is the theoretical and empirical literature in agency theory. The primary research questions are (1) what is the relationship between the size of the supervisory board and the asset turnover ratio (level of agency costs) and (2) what is the relationship between ownership concentration and the asset turnover ratio (level of agency costs) in the Croatian capital market?

The paper is structured as follows. Section 2 is the literature review on theories and studies in the field of corporate governance mechanism. Section 3 is description of methodology of analysis. Econometric model is establishment in section 4. Section 5 discusses the empirical results. Section 6 summarizes conclusion, study limitation and recommendations for future research.

\section{Literature review}

Agency costs, as the most significant principal-agent problem, do not have a directly quantifiable value. Several authors in their empirical studies define measures for the approximation of agency costs. Cerović et al. (2011), Florackis (2008), Junwei et al. (2011), Fauzi and Locke (2012), Ang et al. (2000), Singh and Davidson (2003), Gul et al. (2012), Rashid (2016), Garanina and Kaikova (2016), McKnight and Weir (2009) and Aziz et al. (2015) define total asset turnover as a proxy for agency costs. According to Junwei et al. (2011), McKnight and Weir (2009) and Ang et al. (2000), lower total assets turnover indicates a higher level of agency costs because of inefficient asset utilization. Inefficient asset utilization decreases the wealth of shareholders. Panda and Leepsa (2017) state that total assets turnover explains the efficiency with which the assets are utilized by management and that better utilization indicates lower agency cost. Aziz et al. (2015) claim that increased firm performance decreases agency costs. Junwei et al. (2011) and Aziz et al. (2015) define several governance mechanisms for controlling agency costs: board size, debt financing, and ownership concentration.

\subsection{Board size}

Junwei et al. (2011), Fauzi and Locke (2012) and Florackis (2008) state that a large board is usually more powerful than a small board and obtains better results or that, when board size is larger, agency costs are lower. Fauzi and Locke (2012) also claim that larger companies tend to have larger agency costs and that larger board sizes can reduce agency costs. In contrast, empirical evidence of Junwei et al. (2011) indicates that board size is indistinctively correlated with asset turnover; moreover, they claim that companies with larger board sizes are less efficient in their asset utilization, or that they have higher agency costs. Furthermore, Aziz et al. (2015) and Garanina and Kaikova (2016) state that companies with smaller boards have lower agency costs. Huyghebaert and Wang (2012) claim that, when 
the size of the board increases, the board loses some ability to exert control over key business decisions and the power to ensure that the interests of all investors are realized. Gul et al. (2012) indicate a negative association between board size and the asset utilization ratio; therefore, they indicate that companies with smaller board sizes have lower agency costs. Singh and Davidson (2003) state that board size is negatively related to asset turnover and claim that a larger board size is associated with efficiency losses. Florackis and Ozkan (2004) state that the size of the board has a negative influence on agency costs in terms of asset turnover, which means that, when the board size is larger, agency costs will be higher. Research results conducted by Aziz et al. (2015) on Pakistani companies show a significantly negative relationship with asset turnover because of less effective boards. Garanina and Kaikova (2016) indicate in research conducted on Norwegian, Russian and US companies - that larger boards are associated with higher agency costs in companies. Guney et al. (2020) indicate that a larger board size has an adverse impact on the operational performance of companies. Huu Nguyen et al. (2020) claim that the majority of studies in UK and US indicated a negative relation between board size and firm performance, which imply the higher level of agency costs in companies with larger boards. Previous empirical studies indicated the negative impact of board size on agency costs, so this was the background for our first hypothesis. We are expecting a negative impact of board size on agency costs in Croatian companies.

\subsection{Ownership concentration}

According to Florackis (2008), shareholders with substantial stakes have a greater incentive to supervise management and can do so more effectively than those without substantial stakes, which indicates that higher ownership concentration results in lower agency costs. Aziz et al. (2015) claim that, when the ownership concentration is greater, agency costs are lower. Additionally, Moez (2018) claims that ownership concentration has a negative impact on agency costs. Junwei et al. (2011) state that, when the sum of the stakes of the top ten shareholders is larger, agency costs are lower. Sanda et al. (2010) claim that the effect of ownership concentration is positive on firm performance (return on asset). The results of a study performed by Ang et al. (2000) indicate that agency costs are higher when an agent (outsider) manages the company and that agency costs decrease when the ownership is more concentrated. In contrast, Junwei et al. (2011) indicate a not significant relationship between the sum of the stakes of the top ten shareholders and asset turnover. Aziz et al. (2015) indicate a negative but also insignificant relationship between asset turnover and ownership concentration. Shan and McIver (2011) claim that high levels of ownership concentration will have a negative impact on firm performance because of a conflict between majority and minority shareholders and show research results in support of this conclusion. Moez (2018) ownership concentration has a negative impact on agency costs. 


\subsection{Debt financing}

Jensen and Meckling (1976) explain that debt financing decreases agency costs and increases company value. Florackis (2008: 40) argues that "bank debt has an advantage in comparison to publicly traded debt in monitoring a firm's activities and in collecting and processing information". In addition, Garanina and Kaikova (2016) state that companies with a higher level of debt are better monitored by creditors, resulting in lower agency costs. Junwei et al. (2011), McKnight and Weir (2009) and Fauzi and Locke (2012) state that, when the ratio of total debt to total assets is greater, agency costs are lower. According to Rashid (2016), when a firm relies on debt financing, the interest payment obligation may reduce agency costs. Junwei et al. (2011) claim that the ratio of total debt to total assets is positive. Empirical evidence found by Zhang and Li (2008) supports the thesis that higher leverage can reduce agency costs. McKnight and Weir (2009) indicate that debt is positive and statistically significant, suggesting that companies with more debt tend to have lower agency costs. Ang et al. (2000) state that additional debt decreases agency costs. In contrast, Singh and Davidson (2003) state that leverage is negatively related to the asset turnover ratio. Garanina and Kaikova (2016) indicate that, in US companies, higher debt is associated with lower agency costs, but, in Norwegian companies, higher debt increases agency costs. These results clearly show the different impact which some corporate governance mechanisms have on agency costs depending on market characteristics.

\subsection{Firm growth}

Mendoza and Yelpo (2016) claim that companies with low growth opportunities have a greater possibility of incurring high agency costs when a greater degree of separation exists between ownership and corporate control. Rashid (2016: 614) claim that "growing firms may also achieve economies of scale; this may contribute substantially to reducing their agency cost". Florackis (2008) states that corporate governance mechanisms are expected to be more effective for high-growth firms. The results according to Florackis (2008) support the thesis that the relationship between different governance mechanisms and agency costs is not homogeneous but varies with growth opportunities. In contrast to his claim, his empirical evidence indicated that high-growth firms have lower asset turnover ratios, possibly because of extensive information asymmetries between managers, shareholders and debtholders in high-growth firms. 


\section{Methodology of analysis}

\subsection{Variable measurement, data analysis and results}

Agency costs are not directly measurable, so, in this analysis, an approximation measure was used: asset turnover. Therefore, we used the approximation measure that was used by Cerović et al. (2011), Florackis (2008), Junwei et al. (2011), Fauzi (2012), Ang et al. (2000), Singh and Davidson (2003), Gul et al. (2012), Rashid (2016) and Panda and Leepsa (2017) in their studies. These authors claim that a higher assets turnover indicates lower agency costs.

Dependent variable of the analysis:

1. AGENCYCOSTS ${ }_{i, t}$ - agency costs of company $i$ in year $t$, measured as the total annual income divided by total assets (asset turnover). The data for assets turnover were collected from database INFOBIZZ.

Independent variables, including control variables, for the analysis:

2. BOARD SIZE $E_{i, t}$ - board size of company $i$ in year $t$, measured as the total number of supervisory board members. The data were collected from database INFOBIZZ.

3. OWNERSHIP CONCENTRATION ${ }_{i, t}$ - ownership concentration of company $i$ in year $t$, measured as sum of percentage shares of the top ten shareholders. The data were collected from database INFOBIZZ, company web sites, and other similar sources on the internet.

4. $D E B T_{i, t}$ - debt of company $i$ in year $t$, measured as the total debt divided by the total assets. The data were collected from database INFOBIZZ. Control variable.

5. GROWTH $H_{i, t}$ - growth of company $i$ in year $t$, measured as a percentage increase in sales revenue compared to the previous year. The data were collected from database INFOBIZZ. Control variable.

We conducted a static panel data analysis to test the effects of the corporate governance mechanisms on the agency costs proxies for our panel data sample. The research model is the following:

AGENCYCOSTS $_{i, t}=\alpha_{i}+\beta_{1}$ BOARDSIZE $_{i, t}+\beta_{2}$ OWNERSHIPCONCENTRATION $_{i, t}$ $+\beta_{3} D E B T_{i, t}+\beta_{4}$ GROWTH $_{i, t}+\varepsilon_{i, t}$

$\mathrm{i}=1, \ldots, 109 ; \mathrm{t}=1, \ldots, 5$

where:

$i$ - number of observation units,

$\mathrm{t}$ - number of observation periods, 
$\alpha_{\mathrm{i}}-$ overall intercept term,

$\varepsilon_{i, t}-$ the observation error for $i^{\text {th }}$ units in time $t$, and

$\beta_{1} . ., \beta_{4}$ - beta coefficients.

To test whether the fixed-effects model is more suitable than the combined model, the F-test will be applied, which tests the null hypothesis of the equality of constant members for all spatial units of observation, and, if the null hypothesis cannot be rejected, the model with fixed effects is not appropriate (Wooldridge, 2002; Baltagi 2009; Bahovec and Erjavec, 2009; Skrabić Perić, 2012). The Lagrange Multiplier test (LM) was conducted, in which the null hypothesis assumes that the variance of the random effect of observation units is equal to zero, thus examining the justification of using the random-effect model compared to other models (BreuschPagan test). If the null hypothesis is accepted, the random-effect model is suitable for estimating the parameters in relation to the combined model (Wooldridge, 2002; Baltagi 2009; Bahovec and Erjavec, 2009; Skrabić Perić, 2012). If two diagnostic tests (F-test, LM test) indicate that the combined model is not suitable for estimating parameters, the Hausman specification test will be performed comparing the estimated coefficients of the fixed- and random-effect models. The Hausman specification test examines the null hypothesis, which assumes that both estimators are consistent but that the parameter estimates obtained from the random-effects model are effective, and, if the null hypothesis cannot be rejected, the randomeffects model is more appropriate (Wooldridge, 2002; Baltagi 2009; Bahovec and Erjavec, 2009; Skrabić Perić, 2012).

\section{Empirical data and results}

\subsection{Sample and data collection}

The research was conducted with large Croatian companies that operate in two main categories of economic activity: Manufacturing (C) and Wholesale and retail trade $(\mathrm{G})$. The total number of companies in these categories according to Financial Agency (cro. FINA) was 219, but, for some companies, the data for the observed period, 2014-2018, were not accessible, so those companies were excluded from further observation. The following companies were excluded from the defined sample: companies that did not have supervisory boards, companies that did not operate continuously in the defined period, companies that were in bankruptcy, companies which operate as limited partnerships and companies that did not have supervisory boards continuously in the defined period (2014-2018). The final sample includes 109 large companies. The board structure in the examined companies is the two-tier (Continental type) model. The observed period is defined according to the available data. 
The research includes an analysis of the company's basic financial statements (balance sheet as well as the profit and loss statement) available in the official data from the Statistical Base and the Public Announcement Report of the Financial Agency (cro. FINA). Secondary data were used for the analysis. To obtain financial indicators (assets turnover, firm growth, and debt financing), data were used from the unconsolidated financial statement of companies from 2014 to 2018, accessible in the Financial Agency database (INFOBIZZ). Information about board size was accessible in the Financial Agency database. To obtain ownership concentration, information was used from company web sites, yearbooks and other similar sources on the internet. The aim of this research was to examine the impact of board size and ownership concentration on the level of agency costs according to existing research conducted by Florackis (2008), Junwei et al. (2011), Fauzi (2012), Ang et al. (2000), Singh and Davidson (2003), Gul et al. (2012) and Rashid (2016).

Based on the defined aim of this paper, two research questions were identified:

RQ1: What is the relationship between the size of the supervisory board and the asset turnover ratio (level of agency costs) in the Croatian capital market?

RQ2: What is the relationship between ownership concentration and the asset turnover ratio (level of agency costs) in the Croatian capital market?

According to the literature and past study results, the paper's hypotheses are as follows:

H1: Agency costs will be lower when companies have boards that are small in size.

H2: When the ownership concentration is greater, agency costs will be lower.

Table 1: Descriptive statistics

\begin{tabular}{|l|c|c|c|c|c|}
\hline & $\begin{array}{c}\text { AGENCY COSTS } \\
\text { (asset turnover) } \\
\text { (coefficient) }\end{array}$ & $\begin{array}{c}\text { DEBT } \\
\text { (coefficient) }\end{array}$ & $\begin{array}{c}\text { GROWTH } \\
\text { (percentage) }\end{array}$ & $\begin{array}{c}\text { OWNERSHIP } \\
\text { CONCENTRATION } \\
\text { (percentage) }\end{array}$ & $\begin{array}{c}\text { BOARDSIZE } \\
\text { (number) }\end{array}$ \\
\hline Mean & 1.368294 & 0.540514 & 0.104654 & 0.949249 & 4.355963 \\
\hline Median & 1.080000 & 0.490000 & 0.041184 & 1.000000 & 4.000000 \\
\hline Maximum & 5.720000 & 3.020000 & 19.18736 & 1.000000 & 9.000000 \\
\hline Minimum & 0.060000 & 0.050000 & -0.900381 & 0.000000 & 2.000000 \\
\hline Std. Dev. & 0.924811 & 0.313155 & 1.061647 & 0.140963 & 1.453282 \\
\hline Skewness & 1.540875 & 2.598789 & 15.95420 & -4.088231 & 0.819128 \\
\hline Kurtosis & 5.543204 & 17.29294 & 267.1232 & 22.81004 & 3.328492 \\
\hline
\end{tabular}

Source: Authors'calculations 
Table 1 shows the descriptive statistics for the variables included in the analysis. Agency costs ranged between 0.06 and 5.72. The maximum of this variable is 5.72, indicated the company with the lowest agency costs. Board size ranged between 2 and 9 , and ownership concentration ranged between 0.0 and 1.0. The median of ownership concentration is 1 , which indicates that $50 \%$ of the examined companies have a high level of ownership concentration. Debt ranged between 0.05 and 3.02, and growth, between $-0,9$ and 19.18 . The mean of board size is 4.35 . The mean of ownership concentration is 0.94 which indicates a high ownership concentration in the sample.

To define the appropriateness of the fixed- or random-effects regressions in the sample, diagnostic tests were done. The F-test, LM test and the Hausman test were conducted. The F-test indicated that the fixed-effects model is appropriate, while the LM test indicated the appropriateness of the random-effect model. The Hausman test indicated that the random-effects model is appropriate in our sample of panel data. A random-effects multivariate regression was conducted for companies from 2014-2018 to examine the impact of the selected corporate governance mechanisms (board size and ownership concentration) on agency costs.

Table 2: Panel data - results of analysis

\begin{tabular}{|l|r|r|}
\hline \multicolumn{1}{|c|}{$\begin{array}{c}\text { Dependent variable } \\
\text { AGENCYCOSTS (Asset turnover ratio) }\end{array}$} & \multicolumn{1}{c|}{ Coefficient } & \multicolumn{1}{c|}{ Prob. } \\
\hline Independent variable & & 0.0013 \\
\hline Intercept & 1.344115 & 0.5410 \\
\hline OWNERSHIP CONCENTRATION & 0.253091 & $0.1667^{* *}$ \\
\hline BOARDSIZE & -0.031569 & $0.0537^{*}$ \\
\hline DEBT & -0.140231 & $0.0263 * 3$ \\
\hline GROWTH & & 0.0000 \\
\hline F-test & & 0.3118 \\
\hline Hausman test & & 0.000 \\
\hline Lagrange Multiplier test & & Random effects \\
\hline Selected model & & 545 \\
\hline Total observations & & \\
\hline
\end{tabular}

*significant at the $5 \%$ level; ** significant at the $10 \%$ level

Source: Authors'calculations

The results of the analysis (Table 2) indicated a significant and negative relationship between BOARDSIZE and ASSET TURNOVER at the 10\% level, which means that agency costs are lower when the board size is smaller. DEBT also exhibited a significant and negative relationship with the asset turnover ratio at the $5 \%$ level, 
which means that, at the lower debt level, asset turnover will be higher and agency cost will be lower. GROWTH has a significant and negative relationship with ASSET TURNOVER at the 5\% level. This relationship indicates that companies with lower growth will have lower agency costs. The results also indicated a positive but insignificant relationship between OWNERSHIP CONCENTRATION and ASSET TURNOVER.

\section{Results and discussion}

The results of the analysis indicated that the paper's hypotheses are partially supported. Between board size and asset turnover ratio is indicated significant and negative relationship, which means that agency costs are lower when the board size is smaller. Thus, hypothesis 1 is supported, because companies with a smaller board size will have lower agency costs. These results are in line with Gul et al. (2012), Florackis and Ozkan (2004), Singh and Davidson (2003) and Aziz et al. (2015), which also indicated the negative relationship between board size and asset turnover and which claim that, when the board size is larger, agency costs will be higher. This finding could be interpreted to mean that larger boards will result in higher agency costs because such boards are less effective (Aziz et al., 2015). Debt also exhibited a significant and negative relationship with the asset turnover ratio, which means that, at the lower debt level, asset turnover ratio will be higher and agency cost will be lower. This result is in line with the results found by Singh and Davidson (2003). Some authors claim that a higher level of debt can reduce agency costs (Zhang and Li, 2008; Ang et al., 2000). However, the contradiction in the empirical result could be explained by the various characteristics of the examined market because Garanina and Kaikova (2016) indicate that, in US companies, higher debt is associated with lower agency costs, but that, in Norwegian companies, higher debt is associated with increased agency costs. The Croatian market is more similar to the Norwegian than it is to the US market. Growth has a significant and negative relationship with asset turnover ratio. This relationship indicates that companies with lower growth will have lower agency costs. This result contradicts Mendoza and Yelpo (2016) but is similar to Florackis (2008). The results indicated a positive but insignificant relationship between ownership concentration and asset turnover ratio for Croatian companies. Thus, hypothesis 2 is not supported. These results conform with those of Junwei et al. (2011) and Aziz et al. (2015), which also indicated an insignificant relationship between agency costs and ownership concentration. These results could be affected by the fact that most of the examined companies have a very high ownership concentration, in conformity with the Croatian market.

The main contribution of analysis is to examine if main corporate governance mechanisms as debt and boardsize can controlled agency costs and if defined 
mechanisms are efficient for the principal on the Croatian capital market. Most of the present research have been conducted in US and Chine, so the contribution of a scientific field is to test how the corporate governance mechanisms effected on agency cost for Croatian companies. Also, these results indicate some recommendations for the business community that could be implied. First of all, when forming the size of the board, have to be taken into account that the results indicated that increasing the board reduces its efficiency. In addition, ownership concentration in the observed companies did not prove to be an effective corporate governance mechanism. This can be explained by the high level of concentration of ownership in all these companies.

\section{Conclusion}

The results of the analysis show that the paper's hypotheses are partially supported. Some of the indicated results in this paper are not similar to the results of previous studies. One of the reasons is that the Croatian market is not similar to those found in countries such as the US and the U.K. and has some imperfections. The most significant imperfection is low level of market liquidity. The results of prior studies of the impact of corporate mechanisms on agency costs are inconsistent because their analyses are conducted on markets with different characteristics. These results have to consider the aspects of the tradition of corporate governance in Croatia. Additionally, a different corporate governance model (the Continental type) is dominant in the Croatian market, while most analyses are conducted on the AngloAmerican model. This model characterizes higher ownership concentration, the high level of debt financing, lower level of capital market development and low level of capital market liquidity. The results indicate the negative impact of board size because a larger number of supervisory board members leads to higher agency costs. The impact of ownership concentration as a corporate governance mechanism is not statistically significant. Prior studies indicated debt as a mechanism for decreasing agency costs, but, in our case, debt increases the agency costs. One of the control variables, growth, indicates that companies with lower growth opportunities will have lower agency costs.

This analysis is limited by the data. The analysis did not include all large companies in the Croatian market but only those involved in two main categories of economic activity. For a better representative sample of the research population, an analysis needs to be done on all large companies engaged in all economic activities. We included all large companies from the mentioned economic activities, but because of the inability to collect data we had to exclude some companies. In addition, the extended period (we collected data for 2014-2018) yields certain results. One limitation of the research is that agency costs were approximated through asset turnover ratio because such costs are not directly measurable. 


\section{References}

Ang, J.S., Cole, R.A., Wuh Lin, J. (2000) "Agency costs and ownership structure", Journal of Finance, Vol. 55, No. 1, pp. 81-106, https://doi.org/10.1111/00221082.00201.

Aziz, T., Majeed, S., Saleem, S. (2015) 'The impact of corporate governance mechanism on agency cost: an empirical evidence of Pakistani listed companies', Business, Management and Economics Research, Vol. 1, No. 6, pp. 79-91, Available at: https://arpgweb.com/journal/8/archive/10-2015/6/1 [Accessed: 20.05.2020].

Bahovec, V., Erjavec, N. (2009) Uvod u ekonometrijsku analizu, Zagreb: Element

Baltagi, B. H. (2009) "Longitudinal Data Analysis", Journal of the Royal Statistical Society: Series A (Statistics in Society), Vol. 172, No. 4, pp. 939-940, https:// doi.org/10.1111/j.1467-985X.2009.00614_9.x.

Bendickson, J. et al. (2016) "Agency theory: background and epistemology", Journal of Management History, Vol. 22, No. 4, pp. 437-449, https://doi. org/10.1108/JMH-06- 2016- 0028.

Bhojraj, S., Sengupta, P. (2003) 'Effect of Corporate Governance on Bond Ratings and Yields: The Role of Institutional Investors and Outside Directors', Journal of Business, Vol. 76, No. 3, pp. 455-475, https://doi.org/10.1086/344114.

Cerović, L., Zaninović, V., Dukić, N. (2011) “Utjecaj vlasničke i kapitalne strukture na kretanje agencijskih troškova: studija slučaja vlasnički nisko koncentriranih poduzeća Republike Hrvatske", Ekonomska misao i praksa, No. 2, pp. 419442, Available at: https://hrcak.srce.hr/75566 [Accessed: 10.05.2020].

Eisenhardt, K. M. (1989) "Agency Theory: An Assessment and Review", The Academy of Management Review, Vol. 14, No. 1, pp. 57-74, Available at: https://psycnet.apa.org/doi/10.2307/258191 [Accessed: 20.04.2020].

Fauzi, F., Locke, S. (2012) "Do Agency Costs Really Matter? A Non-linear Approach of Panel Data", Asian Journal of Finance \& Accounting, Vol. 4, No. 1, https://doi.org/10.5296/ajfa.v4i1.1783.

Florackis, C. (2008) "Agency costs and corporate governance mechanisms: evidence for UK firms", International Journal of Managerial Finance, Vol. 4, No. 1, pp. 37-59, https://doi.org/10.1108/17439130810837375.

Florackis, C., Ozkan A. (2004) "Agency Costs and Corporate Governance Mechanisms: Evidence for UK Firms", Working Paper, University of York, UK, Available at: https://www.efmaefm.org/0EFMSYMPOSIUM/2005/ papers/29Aydin_Ozkan_paper.p df [Accessed: 25.04.2020].

Garanina, T., Kaikova, E. (2016) "Corporate governance mechanisms and agency costs: cross-country analysis', Bingley, Vol. 16, No. 2, pp. 347-360, https://doi. org/10.1108/CG-04-2015-0043. 
Gul,et al. 2012) "Agency Cost, Corporate Governance and Ownership Structure (The Case of Pakistan)", International Journal of Business and Social Science, Vol. 3 No. 9, pp. 268-277, Available at: https://ijbssnet.com/journals/Vol_3_ No_9_May_2012/32.pdf [Accessed: 24.04.2020].

Guney, Y., Karpuz, A., Komba, G. (2020) 'The effects of board structure on corporate performance: Evidence from East African frontier markets', Research in International Business and Finance. Elsevier, Vol. 53, No. 101222, https:// doi.org/10.1016/j.ribaf.2020.101222.

Huu Nguyen, A., Thuy Doan, D., Ha Nguyen, L. (2020) "Corporate Governance and Agency Cost: Empirical Evidence from Vietnam", Journal of Risk and Financial Management, Vol. 13, No. 5, pp. 1-15, https://doi.org/10.3390/ jrfm13050103.

Huyghebaert, N., Wang, L. (2012) "Expropriation of Minority Investors in Chinese Listed Firms: The Role of Internal and External Corporate Governance Mechanisms", Corporate Governance: An International Review, Vol. 20, No. 3, pp. 308-332, https://doi.org/10.1111/j.1467-8683.2012.00909.x.

Jensen, M. C., Meckling, W. H. (1976) "Theory of the firm: Managerial behavior, agency costs and ownership structure", Journal of financial economics, Vol. 3, No. 4, pp. 305-360, https://doi.org/10.1016/0304-405X(76)90026-X.

Junwei, W., Guiqin, L., Ping, H. (2011) "Study on the Relationship between Agency Costs and Governance Mechanisms: Evidence from China's A-share Listed Companies". In M\&D Forum Studies, pp. 258-271, Available at: http://www. seidatacollection.com/upload/product/201108/2011gszlhy02a12.pdf [Accessed: 22.05.2020].

La Porta, R. et al.. (2000) "Agency Problems and Dividend Policies around the World", The Journal of Finance, Vol. 55, No. 1, pp. 1-33, https://doi. org/10.1111/0022-1082.00199.

McKnight, P. J., Weir, C. (2009) “Agency costs, corporate governance mechanisms and ownership structure in large UK publicly quoted companies: A panel data analysis", Quarterly Review of Economics and Finance, Vol. 49, No. 2, pp. 139-158, https://doi.org/10.1016/j.qref.2007.09.008.

Moez, D. (2018) "Agency Costs, Corporate Governance and the Nature of Controlling Shareholders: Evidence From French Listed Firms", International Journal of Accounting and Financial Reporting, Vol. 8, No. 3, pp. 256-277, https://doi.org/10.5296/ijafr.v8i3.13621.

Muñoz Mendozaa, J. A., Sepúlveda Yelpob, S. M. (2016) "Does managerial Discretion affect Debt maturity in Chilean firms? An agency cost and asymmetric information approach", Ecos de Economía, Vol. 20, No. 43, pp. 6587, http://dx.doi.org/10.17230/ecos.2016.43.4. 
Panda, B., Leepsa, N. M. (2017) "Agency theory: Review of Theory and Evidence on Problems and Perspectives", Indian Journal of Corporate Governance, Vol. 10, No. 1, pp. 74-95, https://doi.org/10.1177\%2F0974686217701467.

Rashid, A. (2016) "Managerial Ownership and Agency Cost: Evidence from Bangladesh", Journal of Business Ethics, Vol. 137, No. 3, pp. 609-621, Available at: https://link.springer.com/article/10.1007/s10551-015-2570-z [Accessed: 15.04.2020].

Sanda U. A., Mikailu A. S., Garba, T. (2010) "Corporate governance mechanisms and firms' financial performance in Nigeria", Vol. 2, No. 1, pp. 22-39, https:// doi.org/10.1504/AAJFA.2010.035193.

Shan, Y. G., McIver, R. P. (2011) 'Corporate governance mechanisms and financial performance in china: Panel data evidence on listed non-financial companies', Asia Pacific Business Review, Vol. 17, No. 3, pp. 301-324, https://doi. org/10.1080/13602380903522325.

Singh, M., Davidson III, W. N. (2003) "Agency costs, ownership structure and corporate governance mechanisms", Journal of Banking \& Finance, Vol. 27, No. 5, pp. 793-816, https://doi.org/10.1016/S0378-4266(01)00260-6.

Škrabić Perić, B. (2012) Statički panel modeli: primjena u analizi razvoja financijskog sustava zemalja srednje $i$ istočne Europe, Split: Ekonomski fakultet, pp. 173-199.

Wooldridge, J.M. (2002) Econometric Analysis of Cross Section and Panel Data, The MIT Press, Cambridge.

Zhang, H., Li, S. (2008) The impact of capital structure on agency costs: Evidence from UK public companies, Doctoral dissertation, Queens university of technology. 


\title{
Utjecaj veličine nadzornog odbora i koncentracije vlasništva na troškove agenta: Analiza poduzeća u Republici Hrvatskoj
}

\author{
Marina Klačmer Čalopa ${ }^{1}$, Ivana Đunđek Kokotec ${ }^{2}$, Karolina Kokot ${ }^{3}$
}

\begin{abstract}
Sažetak
Glavni cilj ovog istraživačkog rada je ispitati utjecaj veličine nadzornog odbora $i$ koncentracije vlasništva, kao mehanizama korporativnog upravljanja, na troškove agenta u velikim hrvatskim poduzećima. Uz to, ispituje se utjecaj financiranja dugom i stope rasta poduzeća, varijabli koje također mogu imati utjecaj na troškove agenta. Teorija agenta definira okvir za potencijalne probleme koji nastaju prilikom razdvajanja vlasništva $i$ upravljanja, kao $i$ za sukob između vlasnika (principala) i menadžera (agenta). Najznačajniji problem u navedenom odnosu su troškovi agenta, međutim, njih nije moguće izravno mjeriti; sukladno tome u ovom istraživanju autori su troškove agenta aproksimirali putem koeficijenta obrtaja ukupne imovine. Istraživački rad obuhvaća empirijsko testiranje utjecaja veličine nadzornog odbora, koncentracije vlasništva, financiranja dugom i stope rasta poduzeća na troškove agenta u promatranom razdoblju od 2014. do 2018. pomoću analize panel podataka. Istraživanje je provedeno na velikim hrvatskim poduzećima koristeći podatke i informacije iz službenih godišnjih financijskih izvješća kako bi se osigurala objektivnost $i$ usporedivost podataka. Istraživanjem je obuhvaćeno 219 poduzeća koja posluju u sljedećim djelatnostima: prerađivačka industrija (C) i trgovina na veliko i na malo; popravak motornih vozila $i$ motocikala $(G)$ sukladno Nacionalnoj klasifikaciji djelatnosti. Rezultati analize identificirali su značajan i negativan utjecaj veličine nadzornog odbora na troškove agenta. Financiranje dugom i stopa rasta imaju značajan i negativan utjecaj na troškove agenta. Istraživanjem nije utvrđen značajan utjecaj koncentracija vlasništva na troškove agenta.
\end{abstract}

Ključne riječi: Troškovi agenta, korporativno upravljanje, nadzorni odbor, koncentracija vlasništva, analiza panel podataka

JEL klasifikacija: G30, G32, K22

${ }^{1}$ Redovita profesorica, Sveučilište u Zagrebu, Fakultet organizacije i informatike, Pavlinska 2, 42000 Varaždin, Hrvatska. Znanstveni interes: Financijske institucije i tržište kapitala, korporativno upravljanje, strateški menadžment, strategija upravljanja ljudskim potencijalima, institucionalni investitori.Tel.: +38542 390846.E-mail:marina.klacmer@foi.hr.

${ }^{2}$ Asistentica, Sveučilište u Zagrebu, Fakultet organizacije i informatike, Pavlinska 2, 42000 Varaždin, Hrvatska. Znanstveni interes: Financijske institucije i tržište kapitala, korporativno upravljanje, strateški menadžment, institucionalni investitori. Tel.: 38542 390848. E-mail: idjundjek@foi.hr.

${ }^{3}$ Asistentica, Sveučilište u Zagrebu, Fakultet organizacije i informatike, Pavlinska 2, 42000 Varaždin, Hrvatska. Znanstveni interes: korporativno upravljanje, strateški menadžment, strategija upravljanja ljudskim potencijalima.Tel.: +38542 390888.E-mail: kkokot@foi.hr. 